\title{
«Холодная война» в кавычках: фиксация устойчивого выражения в русском публицистическом тексте
}

Ключевые слова: семантика кавычек, метаязыковая рефлексия, политический термин, коммуникативная функция.

Key words: semantics of quotation marks, metalanguage reflection, political term, communicative function.

\begin{abstract}
The article discusses the semantic conditions for quotation mark when using the word combination «Cold War» in Russian-language journalistic and literary texts from the 1950s to the beginning of the $21^{\text {st }}$ century. Various options for the graphic expression of the stable word combination «Cold War» are analyzed from the point of view of the semantics and pragmatics of the text.
\end{abstract}

Этапы вхождения иноязычного слова (выражения, даже семантической кальки) в речевой обиход другого языка часто свидетельствуют об эволюции отношения его носителей к самому явлению, выраженному заимствованной речевой единицей. Разность восприятия предмета обозначения, которая неизбежно отражается на «языковом поведении» слова в принимающем языке, может быть проявлена на многих языковых уровнях. Показательна в этом смысле и письменно-графическая фиксация новой лексической единицы в разные периоды своей адаптации в новом для себя языке [Golev 2013: 13-14].

Выражение «холодная война» как калька с английского «cold war», с момента своего появления в русском языке конца 40-х гг. XX в. [Nadžafov 2003: 84], сразу стало источником множества речевых аллюзий - и культурного, и социально-политического характера. И это неудивительно: и «война», и «холодный» - слова в русском языке чрезвычайно употребительные и частотные, каждое из них ко времени образования нового «лексического союза» имело 
долгую и весьма разнообразную речевую жизнь, что неизбежно отразилось на развитии общей семантики устойчивого словосочетания, а в дальнейшем и семантического расширения исходного значения.

Как следствие, очень скоро «холодная война», помимо основного, социально-политического, терминологического значения ('политика, заключающаяся в нагнетании напряженности, враждебности в отношениях между странами'), приобретает и другое, почти повседневное ('всякая ссора и вражда'), причем как в нейтральном, так и стилистически маркированном контексте, часто с ироническим оттенком: Но в создании и поддержке этой «холодной войны» виновато было начальство [В.А. Маклаков, Из воспоминаний (1954)]; У меня дома такая идет холодная война, лучше не спрашивай [Д. Гранин, Искатели (1954)]; У них свои комнаты, мимо которых Кузнечик старается не ходить. Стая Певчих находится в состоянии «холодной войны» с Хламовными. Обитателей Проклятой комнаты такие мелочи не волнуют [М. Петросян, Дом, в котором... (2009)] ${ }^{1}$ (здесь и далее выделено мной - Т.С.).

Семантическую почву для такого расширительного употребления исконно политического термина подготовило, прежде всего, слово «война», точнее - история его семантических накоплений, явившихся, в свою очередь, следствием исходной синкреты этимологического комплекса значений.

Очевидно, что всякое ключевое слово национальной речевой культуры, обладая глубинным символическим содержанием ${ }^{2}$, на каждом временном отрезке своего существования обнаруживает как «собственное значение», имеющее отношение к данному времени, так и переносное, а в «единстве этих значений указывает на нечто третье, что создает значение общее», символическое [Kolesov 2002: 16].

Известно, что «война» - слово общеславянское [Fasmer 1986, I: 335], в современном русском языке имеющее основное значение 'вооруженной борьбы между государствами' [Ožegov 1990: 97]. Его давно используют и в случаях, когда необходимо подчеркнуть непримиримость всякого противостояния, всякого конфликта, возникающего между людьми: Подсолнечное масло тут вот при чем, - вдруг заговорил Бездомньй, очевидно, решив объявить незваному собеседнику войну [М.А. Булгаков, Мастер и Маргарита, часть 1 (1929-1940)]; Тайная война между Коржаковым и Чубайсом за влияние на Ельиина и за контроль над финансовыми потоками принимала все более ожесточенный характер [В. Баранец, Генштаб без тайн. Книга 2 (1999)].

В «Словаре русской ментальности» В.В. Колесова при слове «война» фиксируется 19 самых частотных эпитетов (в том числе и «холодная»), что

1 Текстовые иллюстрации (здесь и далее) - из Национального корпуса русского языка, http://www.ruscorpora.ru; 12.02.2020.

2 Показательно высказывание В.В. Виноградова «Слово - это символ»; по [Roždestvenskij 1995: 54]. 
свидетельствует о множественности образных форм концепта войны в русских текстах - от «тайной», «жестокой» и «варварской» до «праведной», «яростной» и «справедливой». Само же слово «война» предстает в полноте своих прямых значений, накопленных в течение долгой речевой жизни: это «вооруженная борьба между народами за сферы влияния и богатства, раздор и ратное противостояние воинства с целью защиты своего государства войском, победы над противником или утверждения воином правого дела в бою» [Kolesov 2014, I: 120].

Прилагательное «холодный» имеет не меньшую в сравнении с определяемым словом «война» употребительность: в «Частотном словаре русского языка» это прилагательное отмечено повышенной частотностью, причем без стилистических и иных ограничений [Lâševskaâ, Šarov 2009].

Неудивительно поэтому, что «холодная война» входит в речевой обиход достаточно стремительно - и в силу важности политического явления, актуального для СССР тех лет, и по причине собственно языковой «привычности», а также содержательной ясности этого выражения. Показательно, что в публицистике 40-50-х гг. ХХ в. фиксируется и новообразование «горячая война», принужденное выступать в качестве антонимического к сочетанию «холодная война», хотя до появления переводного выражения необходимости в нем, как известно, не было.

Появление и закрепление в языке (по сути) плеонастического сочетания «горячая война» объясняется рядом причин. Во-первых, действует естественный языковой механизм: сочетание из двух частотных слов русского языка, включенных в обширные лексические системные отношения, неизбежно актуализирует эти отношения на новом семантическом поле. Поэтому столь активно создаются новые антонимические, синонимические к «холодной войне» номинации, т.е. «холодная война» начинает легко вступать в системные связи (антонимические, синонимические, семантико-контекстуальные) с иными словами, имеющими отношение к словам «война» и «холодный»: Мама, а летом холодной войны не бывает? [К.И. Чуковский, От двух до пяти (1933-1965)]; Еще недавно, думая о ней, я сравнивал ее с Багирой, воспоминания о которой согревали меня в затянувшейся холодной войне с Лилей [Б. Левин, Блуждаюшчие огни (1995)]; Мы оказались жертвами агрессии нового типа информационной (т.е. холодной) войны [В. Авилов, Сибирский кулак (2004) // «Боевое искусство планеты», 2004.09.09].

Нюансы отношения к «холодной войне» можно увидеть и в способах письменно-графического представления сочетания: либо в кавычках - либо без них, либо с заглавной буквы - либо со строчной. Подобные варианты написания встречаются в литературе и СМИ по сегодняшнее время: У холодной войны - достаточно примитивная логика: что плохо для СССР, хорошо для США, и наоборот [А. Яковлев, Омут памяти, т. 1 (2001)]; Пик развития волонтёрского движения пришёлся на годы самого жёсткого противостояния 
времён «холодной войны» [Б. Руденко, Волонтёры // «Наука и жизнь», 2009]; В период Холодной войны в глазах политиков по обе стороны от линии фронта ядерная физика была наукой ядерного оружия [Г. Горелик, Послесловие: между прошльмм и будущим. Кризис фундаментальной науки? // «Знание - сила», 2013].

Постановка кавычек - важный знак восприятия языковой единицы в русском письменном тексте [Zaliznâk 2007]; зачастую выступая в роли метаязыкового оператора, этот знак «способен передавать большой спектр коммуникативно актуальных смыслов» [Žukova 2014: 87]. Как правило, в кавычки заключается слово (или выражение), употребленное не в прямом, часто - окказиональном значении, а также слово, имеющее иронический оттенок, как бы обратный в оценочном регистре смысл.

Из традиционно выделяемых четырех функций кавычек в русском языке [Švarckopf 1997: 374] сочетание «холодная война» реализует, как будто, две из них: во-первых, это указание на вторичную мотивированность вполне допустимого словосочетания, и безусловное желание авторов первоначальных публикаций привлечь внимание к этому новому политическому термину.

Следует лишь отметить, что сочетание «холодная война», созданное как лексико-семантическая калька английского «cold war», с самого начала имело закавыченное написание, целиком копируя графический облик иноязычного новообразования, возникшего в англоязычной прессе 1940-50-х гг. по следам знаменитой речи У. Черчилля в Фултоне (5 марта 1946 г.) [Šubin 2013].

Любопытно в этом отношении то, что исконные кавычки этого политологического термина постепенно становятся факультативным графическим знаком. Означает ли это детерминологизацию сочетания, или это изменение отношения (коллективного носителя языка) к факту холодной войны как явлению неординарному?

Показательны контексты 50-х гг. XX в., в которых в кавычки заключено лишь прилагательное «холодная», по мысли авторов, имеющее ярко выраженное переносное значение. «Холодная» война, проводимая по указке Уолл-стрита правительством США, до недавнего времени имела в своей основе надежду недальновидных политиков на монопольное владение секретом атомной бомбы, атомным оружием [Дело Ленина будет жить в веках // «Наука и жизнь», 1950]. Такое употребление слова «холодный» - в кавычках при слове «война» - тут же породило, как уже отмечалось, антонимическую единицу «,горячая" война»: Началась «холодная» война, была опасность, что империализм навяжет нам новую «горячую» войну [Н. Хрущев, Воспоминания (1971)].

Сочетание «горячая война», безусловно, несёт на себе печать вторичности, но с содержательной точки зрения вполне ожидаемо. В понятные семантические отношения вступает, прежде всего, эпитет «холодный», поэтому в кавычки, подчеркивающие эту вторичность, заключаются поначалу прилагательные. 
Однако затем, путем естественной для русской картины мира градации качества «горячести / холодности», возникают сочетания, последовательно развивающие семантические тонкости этого качества: Mы движемся если не к новой «холодной», то весьма «прохладной» войне [Российская газета. Федеральный выпуск. № 0 (3287)]. Типичный эпизод «тёплой» холодной войны: с провокачиями, стрельбой и гибелью людей [Д. Скулачёв, Они были первыми // «Наука и жизнь», 2009]. Заметим, что в кавычки заключаются эпитеты, раскрывающие «степень горячести» конфликта / противостояния, при которой «горячий» становится исходной содержательной формой.

В рамках рассматриваемого сочетания примерно такие же системные отношения демонстрирует и слово «война»; в этих случаях оно закавычивается целиком: Годы после наступления «прохладного мира», а также опасные тенденции во внешней политике Запада после событий II сентября, по сути, подталкивающие «прохладный мир" к «горячим войнам», к сожалению, почти не поколебали, как это ни парадоксально, оптимизм руководства «большой евразийской тройки» в отношении перспектив мирового развития [А. Яковлев, Треугольнику Россия - Китай - Индия нужна стратегия дальних рубежей // «Проблемы Дальнего Востока», 2002.10.28].

Устойчивость, частотность употребления сочетания «холодная война» в его основном, терминологическом значении, а также хорошо проработанный и в специальной литературе, и в СМИ - собственно политологический смысл этого выражения, позволил авторам не пользоваться кавычками: переносное значение этого сочетания почти не ощущается, читатель хорошо понимает, что оно означает. Несмотря на эти расхождения, совещание единогласно признало, что первой причиной венгерской трагедии были, с одной стороны, холодная война с долгими годами ненависти и недоверия, политики блоков, и с другой стороны, ошибки предшествующих правителей Венгрии и использование этих ошибок зарубежной пропагандой [И.Г. Эренбург, Люди, годы, жизнь. Книга 7 (1960-1965)]. Тогда-то американцы организовали «санитарный кордон» против нашей «экспансии», и началась холодная война [Р.Г. Назиров, Дневник (1964)]. Холодная война - это миросозериание, которое введено, безусловно, нами [Ю.К. Олеша, Книга прощчания (1930-1959)].

Выражение «холодная война» неслучайно зафиксировано в словарях русского языка, отмечается его прямое терминологическое значение, не требующее кавычек.

Холодная война - нов. Враждебно-агрессивная политика $[\ldots]$ государств в условиях официального мира. Это было уже в пору фултонской речи Черчилля, объявившего нам «холодную войну». А сейчас мы обмениваемся ульбками, учим иностранщев петь «Катюшу», строим кто как может, смеемся (А. Кравицкий, Память в бессонном карауле) [Fedorov 1995: 72]. 
Холодная война - полит. Военно-политическая конфронтация социалистических и капиталистических государств после 2-й мировой войны [Mokienko, Nikitina 1998: 90].

В качестве синонима к устойчивому сочетанию «холодная война» в начале XXI в. стало активно использоваться выражение «информационная война», видимо, являющееся производным от «холодной войны» в связи с расширением в наше время возможностей информационных технологий, выступающих главным орудием «холодной войны». Метонимическое происхождение «информационной войны» от «холодной» подчеркивается в следующем контексте: Для большинства обывателей гражданская война ассоииируется с тачанкой и буденовкой, но кроме «горячих» есть «холодные» войны, и еще неизвестно, какие из них более убийственны для страны и народа, пример тому - гибель нашей Родины, проигравщей «холодную» (информационную) войну [М. Игорев, Три аршина и земной шар (2003) // «Советская Россия», 2003.02.15].

Очевидно, что выражение «холодная война», первоначально имевшее сугубо терминологическое (политическое / политологическое) употребление, получило широкое распространение в русском языке с момента его появления в 40-ые гг. XX в. Кавычки и другие типы письменной фиксации этого выражения в текстах русских СМИ разных лет демонстрируют различные «взгляды» на это явление: от понимания прямого - политического - значения «холодной войны» до фразеологического, идиоматического, когда прямым оказывается значение исконно переносное.

Некоторые круги Запада теперь стремятся возродить климат холодной войны и разъединить деятелей культуры, преданных делу мира и прогрессу [И.Г. Эренбург, Люди, годь, жизнь. Книга 7 (1960-1965)]; Если правительство нормальное и не собирается вступать на тропу холодной войны, то дело обычно заминается в течение месяиа [Н. Леонов, Н. Геворкян, Кому мешают русские шпионы // «Коммерсантъ-Власть», 1998].

Постановка, частичная постановка или непостановка кавычек при использовании словосочетания «холодная война» фиксирует, таким образом, ту текстовую функцию, которой наделяет его автор текста: в этом отношении исходное политическое значение этого выражения не всегда является основным.

\section{Литература}

Fasmer M., 1986, Ėtimologičeskij slovar' russkogo âzyka, vol. 1, Moskva: Pravda. Fedorov A.I. (ed.), 1995, Frazeologičeskij slovar' russkogo literaturnogo âzyka konca XVIII-XXvv., Moskva: Topikal.

Golev N.D., 2013, Russkaâ pis'mennaâ razgovornaâ reč' i eë otraženie v obydennom metaâzykovom soznanii učastnikov virtual'noj kommunikacii, Vestnik Tomskogo gosudarstvennogo universiteta, 5 (25), pp. 12-30. 
Kolesov V.V., 2002, Filosofiâ russkogo slova, Sankt-Peterburg: Ûna.

Kolesov V.V., 2014, Slovar' russkoj mental'nosti: v 2 t., Sankt-Peterburg: Zlatoust.

Lâševskaâ O.N., Šarov O.A., 2009, Novyj častotnyj slovar' russkoj leksiki, http://dict. ruslang.ru; 20.02.2020.

Mokienko V.M., Nikitina T.G., 1998, Tolkovyj slovar' âzyka Sovdepii, Sankt-Peterburg: Folio-Press.

Nadžafov D.G., 2003, K voprosu o genezise holodnoj vojny [in:] N.I. Egorova, A.O. Čubar'ân (eds.), Holodnaâ vojna: 1945-1963 gg. Istoričeskaâ retrospektiva, Moskva: OLMA PRESS, pp. 65-103.

Ožegov S.I., 1990, Slovar' russkogo âzyka, Moskva: Russkij âzyk.

Roždestvenskij Û.V., 1995, Viktor Vladimirovich Vinogradov, Vestnik $M G U, 1$, pp. 51-54.

Šubin A., 2013, Holodnaâ vojna, https://www.krugosvet.ru; 20.02.2020.

Švarckopf B.S., 1997, «Â postavil kavyčki, potomu čto...» [in:] L.P. Krysin (ed.), Oblik slova: Sbornik statej pamâti Dmitriâ Nikolaeviča Šmeleva, Moskva: IRÂ RAN, pp. 374-381.

Zaliznâk A.A., 2007, Semantika kavyček [in:] L.L. Iomdin, N.I. Lajfer, A.S. Narin'âni (eds.), Komp'ûternaâ lingvistika i intellektual'nye tehnologii: Trudy meždunarodnoj konferencii «Dialog 2007», Moskva: Izd-vo RGGU, pp. 188-193.

Žukova A.G., 2014, Kavyčki v diktante i vne ego, Vestnik Novosibirskogo gosudarstvennogo universiteta, 13 (9), pp. 82-87. 